\title{
Влияние нефтяного загрязнения на всхожесть и морфометри- ческие показатели растений семейства Fabaceae
}

\author{
() Ю.М. Сотникова*, Р.Г. Фархутдинов \\ Башкирский государственный университет \\ Россия, Республика Башкортостан, 450076 г. Уфра, улица Заки Валиди, 32 \\ *Email: sotnikova-bashedu@mail.ru
}

На сегодняшний день загрязнение нефтью и нефтепродуктами является одной из основных проблем в биологии. Фиторемедиация считается одним из перспективных методов восстановления земель, загрязненных нефтью и нефтепродуктами. Все большую актуальность приобретает поиск растений, обладающих способностью к фиторемедиации нефтезагрязненных земель.

Ключевые слова: люцерна посевная, фриторемидиация, нефтяное загрязнение

Главное требование, предъявляемое к растениям-фриторемедиантам - это высокая адаптивная устойчивость к действию загрязнителя [1]. Растения-фриторемедианты также должны обладать высокой скоростью накопления биомассы, способностью поглощать и накапливать тяжелые металлы и другие ксенобиотики, а также активизировать деятельность почвенных микроорганизмов [2,3,4]. Продолжаются поиски растений, пригодных для фриторемедиации, предполагающей извлечение поллютантов из загрязненных почв корневой системой растений с последующим их переносом и аккумуляцией в надземной части растений $[5,6]$. Множество исследований посвящено поиску растений, обладающих устойчивостью к нефтяному загрязнению, в связи с чем, целью данной работы явилась оценка устойчивости к нефтяному загрязнению растений семейства Бобовые (Fabaceae).

Материалы и методы. Объектами исследования были растения семейства Бобовые (Fabaceae) (люцерна посевная (Medicago sativa L.), клевер луговой (Trifolium pratense L.), донник желтый (Melilotus officinalis L.), вика посевная (Vicia sativa L.)).

Для оценки всхожести семян в условиях нефтяного загрязнения в чашки Петри помещали по 100 г почвы, вносили нефть в концентрациях 1\%, 3\%, 4\%, 6\% и 8\% от сухой массы почвы. В качестве контроля использовали незагрязненную почву. Через 3 суток в почву вносили семена исследуемых растений в соответствии с нормами высева для каждой культуры [7]. Оценку результатов проводили через 7 суток. Отмечали количество проросших семян в опытном и контрольном варианте.

После определения фритотоксичности почвы проводили оценку устойчивости растений к условиям длительного нефтяного загрязнения. Растения выращивали на серой лесной почве в сосудах объемом 0,5 л. Вносили нефть в концентрациях 1\%, 3\%, 4\%, 6\% и $8 \%$ от сухой массы почвы. Почву увлажняли и поддерживали на протяжении всего периода выращивания. Через 3 суток в почву вносили семена исследуемых растений в соответствии с рекомендациями для каждой культуры [7]. В контрольном варианте эксперимента растения выращивали без внесения нефти.Сравнительную оценку устойчивости проводили через 30 суток. 
Статистическую обработку полученных результатов проводили с использованием пакета прикладных программ Statistica 10.0, рассчитывали средние значения, стандартные отклонения и доверительный интервал при $P \leq 0,05$.

Результаты и обсуждение. Была проведена оценка способности семян к всхожести в условиях нефртяного загрязнения (табл. 1).

Как видно из табл. 1 всхожесть семян на незагрязненной почве у представителей семейства Бобовые (Fabaceae) - люцерны, клевера, донника составляла более $90 \%$, а у вики была ниже $90 \%$.

Таблица 1. Влияние уровня нефтяного загрязнения почвы на всхожесть семян растений разных видов, \%

\begin{tabular}{|l|c|c|c|c|}
\hline & Люцерна & Клевер & Донник & Вика \\
\hline Контроль & $96 \pm 2$ & $93 \pm 1$ & $93 \pm 1$ & $86 \pm 7$ \\
\hline Несть 1\% & $\mathbf{8 8 \pm 1}$ & $\mathbf{8 4 \pm 3}$ & $\mathbf{8 2 \pm 1}$ & $\mathbf{8 2 \pm 8}$ \\
\hline Нефрть 3\% & $\mathbf{8 2 \pm 1}$ & $74 \pm 3$ & $71 \pm 4$ & $68 \pm 8$ \\
\hline Нефрть 4\% & $\mathbf{7 8 \pm 4}$ & $67 \pm 3$ & $57 \pm 6$ & $29 \pm 8$ \\
\hline Нефть 6\% & $62 \pm 3$ & $60 \pm 6$ & $34 \pm 4$ & $16 \pm 1$ \\
\hline Несть 8\% & $53 \pm 4$ & $51 \pm 4$ & $14 \pm 1$ & $11 \pm 1$ \\
\hline
\end{tabular}

Примечание: представлены средние значения и их стандартные ошибки; отличия от контрольных образцов при $P \leq 0,05$.

В случае загрязнения при концентрации 1\% и 3\%, значительного снижения всхожести семян у бобовых, за исключением вики, по сравнению с контрольными образцами не наблюдалось (табл. 1), что указывает на низкий фитотоксический эффрект данных концентраций. При концентрациях нефти $6 \%$ и $8 \%$ было выявлено значительное ингибирующее действие на все исследуемые виды растений и всхожесть семян варьировала от $11 \%$ (вика) до 53\% (люцерна). Таким образом, при содержании нефти в почве в концентрации 4\% и ниже, не наблюдалось значительного фритотоксического действия на всхожесть семян уисследуемых растений семейства Бобовых. Наименьший токсический эфрфект нефтяного загрязнения на всхожесть семян был установлен у семян люцерны.

Оценка влияния длительного выращивания растений в присутствии нефти на морфометрические показатели растений семейства Бобовые показала, что при загрязнении почвы $1 \%$ нефтью, средние значения показателей практически не отличались от контрольных значений, но при повышении концентрации загрязнителя до 6\% и 8\% средняя длина проростков значительно уменьшалась (табл. 2). Растения люцерны, при внесении 4\% объема нефти в почву, снижали скорость ростовых процессов в меньшей степени по сравнению с другими растениями (табл. 2). Рост корней также снижался: в наименьшей степени у люцерны (на 28\%), и более значительно у остальных культур (клевер, донник, вика) соответственно, на 40, 30 и 60\% (табл. 2). 
Таблица 2. Влияние нефтяного загрязнения почвы на длину побега (П) и корня (К) растений разных видов, см

\begin{tabular}{|c|c|c|c|c|c|}
\hline & & Люцерна & Клевер & Донник & Вика \\
\hline \multirow[t]{2}{*}{ Контроль } & $\Pi$ & $3,2 \pm 0,02$ & $2,7 \pm 0,03$ & $2,8 \pm 0,04$ & $2,3 \pm 0,04$ \\
\hline & $\mathrm{K}$ & $3,5 \pm 0,01$ & $3,7 \pm 0,01$ & $3,0 \pm 0,04$ & $2,3 \pm 0,02$ \\
\hline \multirow[t]{2}{*}{ Несрть 1\% } & $\Pi$ & $3,1 \pm 0,04$ & $2,6 \pm 0,03$ & $2,7 \pm 0,03$ & $2,0 \pm 0,02$ \\
\hline & $\mathrm{K}$ & $3,1 \pm 0,04$ & $3,1 \pm 0,04$ & $2,8 \pm 0,04$ & $2,0 \pm 0,02$ \\
\hline \multirow[t]{2}{*}{ Нефтть 3\% } & $\Pi$ & $2,9 \pm 0,04$ & $2,2 \pm 0,02$ & $2,6 \pm 0,03$ & $1,5 \pm 0,02$ \\
\hline & $\mathrm{K}$ & $2,7 \pm 0,03$ & $2,7 \pm 0,03$ & $2,5 \pm 0,03$ & $1,5 \pm 0,02$ \\
\hline \multirow[t]{2}{*}{ Нестьь 4\% } & $\Pi$ & $2,7 \pm 0,03$ & $2,1 \pm 0,02$ & $2,1 \pm 0,02$ & $0,9 \pm 0,01$ \\
\hline & $\mathrm{K}$ & $2,5 \pm 0,03$ & $2,2 \pm 0,02$ & $2,1 \pm 0,02$ & $1,1 \pm 0,01$ \\
\hline \multirow[t]{2}{*}{ Нефрть 6\% } & $\Pi$ & $2,0 \pm 0,02$ & $1,1 \pm 0,01$ & $1,1 \pm 0,01$ & $0,5 \pm 0,01$ \\
\hline & $\mathrm{K}$ & $1,9 \pm 0,01$ & $2,0 \pm 0,03$ & $1,8 \pm 0,02$ & $0,7 \pm 0,01$ \\
\hline \multirow[t]{2}{*}{ Нефрть 8\% } & $\Pi$ & $1,7 \pm 0,01$ & $0,9 \pm 0,01$ & $0,6 \pm 0,01$ & $0,3 \pm 0,01$ \\
\hline & $\mathrm{K}$ & $1,7 \pm 0,01$ & $1,5 \pm 0,01$ & $1,3 \pm 0,01$ & $0,3 \pm 0,01$ \\
\hline
\end{tabular}

Примечание: представлены средние значения и их стандартные ошибки; отличия от контрольных образцов при $P \leq 0,05$.

Таким образом, в ходе оценки влияния нефтяного загрязнения на всхожесть и морфометрические показатели растений семейства Бобовые было установлено, что наиболее устойчивы проростки люцерны посевной. Наиболее «оптимальный» для сохранения всхожести семян и роста исследуемых растений объем нефртного загрязнения $4 \%$.

Относительно устойчивая всхожесть семян и рост проростков растений семейства Бобовые были установлены у люцерны посевной в опытах с 4\% содержанием нефти в почве, поэтому эти растения могут быть рекомендованы для фриторемедиации земель подвергнутых нефтяному загрязнению.

\section{Литература}

1. Панченко, Л.В. Атлас растений-фиторемидиантов /Л.В.Панченко, А.Ю.Муратова, Е.В.Дубровская, С.Н.Голубев, М.А.Березуцкий, О.В. Турковская. - Саратов: Научная книга, 2015. - 560 с. 
2. Башмаков, Д.И. Аккумуляция тяжелых металлов некоторыми высшими растениями в разных условиях местообитания /Д.И.Башмаков, А.С. Лукаткин. -Агрохимия, 2002. - № 9. - C. 66-71.

3. Тафеева, Е.А. Содержание тяжелых металлов и нефтепродуктов в почве на территории нефтедобывающих районов Республики Татарстан / Е.А. Тафееева, А.В.Иванов, А.А.Титова, И.В. Петров. -Гигиена и санитария, 2016. - 95(10). - С. 939-941. DOI: http://dx.doi. org/10.18821/0016-9900-2016-95-10-939-941

4. Prabha, J. Opportunities and challenges of utilizing energy crops in phytoremediation of environmental pollutants / J. Prabha, M. Kumar, R. Tripathi. - Bioremediation for Environmental Sustainability, 2021. - Elsevier. - Chapter 17. -P.383-396.

5. Киреева, Н.А. Подбор растений для фиторемедиации почв, загрязненных нефтяными углеводородами / Н.А. Киреева, А.С. Григориади, В.В.Водопьянов, А.Р. Амирова // Известия Самарского научного центра Российской академии наук, 2011. - Т. 13. - № 5(2). - C. 184-187.

6. Trakal, L. Phytoextraction of Metals: Modeling Root Metal Uptake and Associated Processes/ L. Trakal, D. Martínez-Fernández, M. Vítková, M. Komárek. - Phytoremediation Management of Environmental Contaminants, 2015. -V. 1. -P. 69-86.

7. Фирсов, И.П. Технология производства продукции растениеводства / И.П. Фирсов, А.М. Соловьев, М.Ф. Трифонова. - М.: КолосС, 2006. - 472 с. 